\title{
Unity in fragility: nonviolence and COVID-19
}

\author{
Roberto Baldoli $^{1}$ (D) and Claudio M. Radaelli ${ }^{2 * \dagger}$ \\ ${ }^{1}$ School of Public Policy, University College London, UCL, London, UK and ${ }^{2}$ School of Transnational Governance, European \\ University Institute, Florence, Italy \\ *Corresponding author. Email: claudio.radaelli@eui.eu
}

(Received 18 November 2020; revised 12 August 2021; accepted 12 August 2021; first published online 6 September 2021)

\begin{abstract}
The COVID-19 pandemic witnessed extreme forms of biopolitics, as well as the urgency to reconsider our relationship with the planet. Although biopolitics draws attention to the technologies of domination by public authorities, we cast the concepts of bios and politics in the wider framework of nonviolence. In this framework, bios is the set of practices (praxis) of ordinary citizens. And politics is power created by harm reduction, or actions in daily life that testimony the desire not to harm others or the planet. We leverage nonviolence at three levels, scaling up from the individual to social behaviour and to the planet. The first level concerns nonviolence as self-sufferance and as praxis to claim back the sovereignty of the body. In the second level, nonviolence is collective mobilization - building social capital, self-governance, and solidarity. The third level provides the vision of a diverse ecological citizenship with a sustainable relationship between human beings and the planet.
\end{abstract}

Key words: biopolitics; COVID-19; environment; mobilization; nonviolence; sustainability

\section{Biopolitics and necropolitics}

The COVID-19 pandemic has exposed the fragility of our social and personal existence and life on the planet. It has also revealed the limits of a mode of production where humans produce the conditions for the birth and spread of viruses' outbreaks via deforestation, mass consumption of animals, and global food chains. Behind this mode of production - some have argued - lies a mode of bio-governance which privileges the prosperity of human society - considered a superior species - at the expenses of the 'pure and timeless collection of objects' called nature (Cavanagh, 2014: 278). Such a relationship triggers an 'incremental and accretive' kind of violence which occurs 'gradually and out of sight' (Nixon, 2011). For Nixon, this is 'slow violence', stressing the dimension of time and imperceptible change and the artificial division between human action and environment.

Bio-governance has gained another dimension during the pandemic. In fact, the governance of our daily lives and bodies has caused public anxieties for the rise (and possibly institutionalization of) measures limiting freedom and personal liberties of citizens, from Italy to Norway (Gjerde, 2021). For some observers, the policy responses herald a transition towards a permanent state of exception (Agamben, 2020), in which states overcome the rule of law and democratic procedures. In this sense, under conditions of permanent exception, the governance of lives and species takes on the connotations of the Foucauldian concept of bio-politics. Authors such as Zuboff (2019) warned before the pandemic about the risk of surveillance capitalism and its political implications. However, with the different waves of the pandemic, European

\footnotetext{
${ }^{\dagger}$ On long-term leave from UCL, School of Public Policy, London, UK.

(c) The Author(s), 2021. Published by Cambridge University Press on behalf of the Società Italiana di Scienza Politica. This is an Open Access article, distributed under the terms of the Creative Commons Attribution licence (http://creativecommons.org/licenses/by/4.0/), which permits unrestricted re-use, distribution, and reproduction in any medium, provided the original work is properly cited.
} 
citizens got used to inter-personal distancing, border restrictions, travel bans, wartime-like curfews, almost total business closure, and empty streets. According to political theorists such as Roberto Esposito, COVID-19 has brought about a process of 'medicalisation' of politics, with governance confined exclusively to risk management, together with a 'politicisation of medicine', with medical experts' advice heavily influenced by social and economic contexts (Esposito, 2020).

And biopolitics (Foucault, 1998) may have already blended with necropolitics. The health crisis touched the most personal existential sphere - changing our relationship with life and death. With the pandemic exposing new dynamics of control over life and death of and by people (Robertson and Travaglia, 2020), a novel necropolitics has infected European societies (Mbembe, 2019). This 'ultimate expression of sovereignty' then relates to state power in a very significant way - we are talking about the possibility to decide on the life and death of citizens. Some people have been given preferential treatment while others have not even been provided with a place in hospitals. Some deaths have not even been counted. Bodies have been separated from families and cremated with strict and special protocols. This outcome is connected to past economic decisions about the provision and organization of health care - leaving governments today to administer life through non-medical state control and violence towards non-citizens (Lee, 2020). Finally, the pandemic and its policy responses have exposed the artificiality of the boundary between the public and the private, highlighting the social consequences of our daily choices and action for others and the society in general.

The full range of policy measures introduced in response to the pandemic is already the subject of a nascent field of comparative studies showing common themes and cross-national variation (Capano et al., 2020; Weible et al., 2020). Whether we look at policy or politics, governments or citizens, necropolitics or live-saving health, and trade measures, the COVID-19 plot is thick.

We do not take positions on the debate on biopolitics and whether this has mutated into necropolitics. Instead, we move our analytical lens onto something completely different from public authorities and the exercise of state power under exceptional conditions. We look at examples in which daily human actions, precautionary attitudes, self-sufferance - in short: the purest, simplest acts of human life as bios - create power and social resiliency to reverse the degenerations of biopolitics and necropolitics. This is the focus of our article, empirically limited to the European scene - although we believe that our argument has a wider resonance. Specifically, we leverage one analytical framework, that is, nonviolence, to explore the three levels of the individual, the social, and planetary-sustainability dimensions of this unprecedented crisis. As it is often the case, social research makes progress in complex questions at its best by embracing one analytical tool or framework and exploiting its potential.

The research questions that motivate us are therefore grounded in the framework we have chosen. Specifically, our first research question is how (spontaneous or in some ways steered or caused by governmental measures) and where (the individual or group dimension) has nonviolence as practice emerged during the pandemic? The second research question is about the implications of what we can observe (by focusing on nonviolence) in terms of human behaviour, society, and politics. The third question is normative, that is, how can our analysis of nonviolence contribute to reverse violence against the environment, state of exception, and necropolitics? We find that the rise of nonviolence was more spontaneous than hetero-directed by the need to comply. Our observations on self-suffering point towards an ultimate form of sovereignty that stands up to the increasing governmental power on life and death. On the normative side, we argue for self-governance and the Gandhian concept of 'uplift of all' as praxis that can counter the rise of the state of exception. We hasten to add that the normative implications of nonviolence are not ideological or about specific final ends of history. They are about praxis, because nonviolent actions are ends-creating, not the opposite (Mantena, 2012).

One important caveat: we are not claiming that empirically the evidence pointing to nonviolence has overcome the many documented episodes of physical and emotional attacks on women and children in their own houses; the anti-lockdown mobilizations without inter- 
personal distancing in many European cities; the refusal to get the vaccine in a non-trivial percentage of the population; and the simple fact that many individuals, in some cases even people with responsibility in government, did not respect public health regulations. As will be clear in the conclusions, we argue that nonviolence springs from individuals and societies, but its diffusion and consolidation should not be taken from granted - we cannot bracket away institutional responses and policies. When we say that nonviolence is a lens, we mean that it sheds lights and magnifies the conceptual and political importance of certain phenomena. We simply take what we see under this lens and explore the implications for the individual, social, and planetary dimensions. We are also aware of the utopian quality of nonviolent political theory, but this should not deter us from using it in the social science, especially at a time when even public administration and public management turn their attention to utopias about governance (Ongaro, 2020).

In terms of organization: we will start with a clarification about how we use the concept of nonviolence as a framework centred on interrelatedness of life, freedom, and plurality. Then, we will focus on nonviolence at the individual level. We will argue that some important, empirically observed individual responses are a form of self-suffering. Next, we will turn to the meso-level of collective behaviour and observe nonviolence as a suite of styles of collective mobilization. Section four (the section on the macro level) will focus on the nonviolent approach to the planet as a form of diverse ecological citizenship which includes strategy, self-scrutiny and day-to-day creation of a new reality with nature. In the conclusions, we will answer our research questions, looking and challenges and opportunities of this approach.

\section{The pandemic and nonviolence}

At first glance, an observer may be led to the conclusion that the worsening of the subjugation of bodies (and nature) and of the control of the population made possible by the pandemic is the burial moment of decades of knowledge and skills on the topic of nonviolence. All we have seen portrayed in the media is a world of fear, politicians, and experts calling every shot without meaningful parliamentary debate, rise of the power to dictate life, and death of citizens in the name of emergency, and cities reduced to empty spaces.

To see how nonviolence has a place in this narrative, we must be clear on our usage of the concept. Nonviolence is often associated with (we would say 'regrettably reduced to') a set of techniques of action short of violence or with the strategy of movements that eschew the use of violence (Sharp, 1973). In the attempt to widen the intension of the concept (i.e. the list of properties that make up nonviolence), we draw on a rich but definitively not homogenous scholarship (Sharp, 1973 for nonviolence as tactics and strategies; Atack, 2012 on the political theory of nonviolence; Jahanbegloo, 2014, 2021 on the contemporary debates; Nagler, 2014 on principled nonviolence; and more recently Baldoli, 2018 on reconstructing nonviolence). We build on the classical definition of nonviolence as ahimsa, the force unleashed by actions and practices (praxis) that have one property or important 'residual': they limit or eradicate the desire to harm. This definition embraces the principled and tactical meanings of nonviolence. Indeed, it includes strategic, ethical, and religious dimensions generated by praxis. Hence, we are within an intellectual range captured by the Gandhian's approach to nonviolence - as explained and expanded by Jahanbegloo (2021).

Yet, the Gandhian notion of nonviolence - which is the one adopted in this article - should not be confused neither with simple non-injury or non-killing, nor with withdrawal from society. It deals with proximity, selfless service, empathy, and citizenship. Its extension (i.e. the range of phenomena it applies to) is wider than individual or collective action without weapons or physical violence. Gandhi brought the traditional religious conception of ahimsa (see Jahanbegloo, 2014) at the centre of a social and political project to face the violence embedded in the 19 th century modern western civilization process, characterized by competition, greed, and avarice 
(Gandhi, 1997). Nonviolence, following Nagler's interpretation of Gandhi, is thus 'a positive force' (Nagler, 2014: 45) (a 'positive force of love' in Gandhi, 1920: 2). This force is created when in an individual or collective action the desire to harm is not simply eradicated, but is converted into 'creative equivalents such as love and compassion', 'showing an alternative path (what Gandhi called constructive programme) to the status quo. This is the only force that persists in the midst of destruction (Gandhi, 1942) - able to confront the rising violence in society.

Elaborating on the definition, we approach nonviolence as a creative framework of action which is at the same time empirical - allowing researchers to see existent practices, power relationships, and democratic governance under a new light - and normative - that means, it allows us to appraise and improve reality (Baldoli and Radaelli, 2019: 1168). Note that this framework has a normative dimension but not in the sense of prescribing an abstract, rigid system of thought to be implemented in reality. Its normative core lies in human actions and practices, in the relations among individuals. It is the action that is normatively rich. Scholars of nonviolence such as Nagler (2014), drawing on the ancient notion of quality (or 'residual') of action found in the Bhagavad-Gita, underline the force or power generated by praxis directed by the intention not to harm.

This last observation takes us immediately into the notion of nonviolence as a type of emergent power (Adler-Nissen and Pouliot, 2014; Baldoli and Radaelli, 2019). Human beings have the chance to use their body and life to change their communities and governance. This form of power that springs from action is held by any individual - 'person power' for Nagler (2014) and by their decision to come together in collective action. Gene Sharp labelled the collective manifestation of person power 'people power' (Sharp, 1973), adding that governments have power only until citizens allow them to exercise this power over them - this is the consent theory of power. Kaplan showed that local communities can withdraw consent and create their own power to protect themselves even in extreme contexts, such as when dealing with armed groups (Kaplan, 2017).

We realize we have cut corners in the presentation of nonviolence. However, it is necessary to move quickly to the implications of what we are saying: what does nonviolence 'do' to the people and societies that adopt it in their individual and social action? Why do some authors such as Peter Ackerman and Jack DuVall (Ackerman and DuVall, 2001) call nonviolence 'the force more powerful'? Nonviolence creates phronesis (Baldoli, 2018), an evolving practical wisdom made of actions and practices directed to change qualitatively our social and political reality. This practical wisdom is transformative. It develops what Gandhi called swaraj (self-rule and self-governance) and sarvodaya (the welfare of all) (Bondurant, 1988, original edition 1958; Gandhi, 1997), Aldo Capitini named liberazione (liberation from biological and historical determinism) (Capitini, 1998), and apertura (openness to the other). Furthermore, interpreting Arendt's observations on praxis and Jahanbegloo's observations on individual and collective autonomy, this liberating force leads to freedom and plurality (Arendt, 1998; Jahanbegloo, 2021:34). These terms highlight the capacity of each person to rise from passivity and start something qualitatively new - beginning from the re-appropriation of her or his own body to collective identities. By nurturing nonviolent praxis in society and politics, communities of people achieve the liberation of bodies, populations, and nature from discipline and control from above. They create bottom-up new identities and relationships.

\section{The individual level: self-sufferance as the ultimate expression of sovereignty}

After these clarifications on the concept of nonviolence, we zoom on its relationship with the pandemic. Recall that our first research question is how and where nonviolence emerged during the hardest stage of the pandemic in Europe. We start from the individual level. The pandemic triggered both the fear of death and the realization of inter-dependence of all humans and things. Both are key to nonviolence. The 'awakening moment' for nonviolence is the acknowledgement

${ }^{1}$ https://mettacenter.org/nonviolence/introduction/. 
that we are all fragile and unite in the biological cycle of life and death (Capitini, 1998) - the essential unity of man and for that matter of all that lives (Gandhi, 1996). It is exactly at this profound level that we are all equal and bound by the same destiny. The contagion put in front of us this truth in the crudest possible ways, ignoring differences of economic and social status. It showed no respect for borders, ethnicity, or social occupation. The virus outbreak affected the very day-to-day experience: actions and behaviour that, especially in the Global North, are taken for granted, were seen in a new light of fragility and contingency of human beings (nobody was and still is immune from the risk of death and pain) and their constitutive interdependence (realizing how much our survival and well-being depends on the others).

There are two possible responses to this state of play. One is closure in ourselves and our fear. The other, embraced by many citizens of very different age, gender, social status, and ethnicity, is to develop openness to the others. An economist would talk of internalizing the value of the life of others. Aldo Capitini, the Italian philosopher of nonviolence who lived at the time of Mussolini, would point to apertura (literally: openness). Jahanbegloo (2020: 61), elaborating on Gandhi's critique of western civilization, argued that 'the coronavirus has revived a sense of empathy that was concealed for half a century by utilitarian and materialistic modes of human life'.

Crucially, this process of openness and empathy is incarnated in daily self-restraint. Most of us decided (and in some countries are still deciding today) to voluntary suffer and impose limits to daily behaviour, including leaving groceries on the door of our parents and elderly friends and relatives, without even hugging them. It's hard to think that people did or are doing all these things because they were afraid of sanctions or police controls: there isn't and won't ever be a cop in front of every house, an enforcement officer for every family. It's simpler to think of these actions as tapasya - self-sufferance that prefigures a better reality for all.

Self-sufferance is the quality that strikes us as most important for a nonviolent understanding of behaviour during the pandemic. It has obvious implications for the 'residual', that is, the consequences for others of a particular action. But, note, tapasya is not self-abnegation and withdraw from reality. It points to the exact opposite. Tapasya incarnates (from the Latin incarnare, to make flesh) the conscious, active, reality-oriented use of own's body as liberation and constructive tool (Van Goelst Meijer, 2017).

In Gandhi and more generally in the literature on nonviolence, self-suffering is central to the so-called law of suffering. This law points to a mechanism that reaches the heart and transforms the opponent. This presumes the existence of a relationship between people. With COVID-19, selfsuffering is a way to fight a virus that cannot be persuaded to desist. Therefore, why calling these actions tapasya and not simple self-sacrifice? COVID-19 is a threat to human existence, there isn't a situation of asymmetry of power relations. Some may wrongly consider both nature and the others as enemies in the war against the pandemic. The answer is and cannot simply be self-sacrifice to help others in a war against nature. We still have to move the focus from the actors - in this case the other and nature - to the quality of the relationship itself. This quality lies in the constructive bridge with the other, the individual-institutions nexus, and nature. Thus, we may still keep the focus on persuasion - not conceived as 'I persuade you that I am right' but as a path towards understanding, reconciliation, and transformation to overcome the crisis. The constructive quality of this relationship lies in the possibility to achieve a better balance with both human beings and their development within (and not against) the planet. Recalling the famous Gandhian say that 'suffering is the badge of the human race, not the sword' (Gandhi, 1999: vol. 48, 189, as quoted by Jahanbegloo, 2021: 59), we argue that suffering is also the badge of other beings and nature.

This form of self-sufferance is resistance to the top-down administration of death, and protection of life. Indeed, life-protecting behaviour is crucial to the success of the most delicate policies introduced during the acute stage of the spread of the contagion, as shown in the national lockdown in Italy in Spring 2020 and then later in the regional lockdowns in the second wave. Reflecting on the behaviour of European citizens, economists such as Carlin (2020) argue that this life-protecting behaviour changes the classic narrative of public policies being either state-led 
or market-led. For her, individual behaviour during lockdown provides ample illustrations of citizens-led policies. Ultimately, citizens are co-designers of policies - to hear this from a professional economist like Carlin is refreshing. Citizens are responsible for public policies and their success. Public policy action often originates from the citizens' activity, with the government following on and locking in the benefits in policy and institutional choices (Voorberg et al., 2015). The former governor of the Bank of England, Mark Carney, argued in similar ways that 'the traditional drivers of values have been shaken' (The Economist, 'By Invitation' series, https://www. economist.com/by-invitation/).

The most common form of self-suffering in the context of local or nationwide spread of the virus is self-isolation in the presence of symptoms or risk factors (such as having visited a country with high contagion coefficient). In a subtle but effective way, this individual decision, taken by thousands of citizens in every country, is a practical way to challenge necropolitics. To put it bluntly, I challenge necropolitics with my body. I (not my government/not the World Health Organization) exercise the power to decide on life and death - my life but also the lives of people who live with me, close to me, or may encounter me if I go out.

The most extreme form of self-suffering we witnessed during the pandemic is giving up freedom voluntarily, reporting ourselves to the health authority and agree about being isolated in hospitals for the good of the community, with the risk of dying alone and far from the dearest ones. The seriousness of the decision is evident in the accounts of the hospitalization of many people infected by the virus. This decision has a self-interested dimension, because people want to protect their life at any cost. But, taken comprehensively, it has value as extreme duty for the good of the others.

When, during the acute phases of the pandemic waves, governments seemed to be left with the task of administration of death, necropolitics was countered by a full repertoire of individual actions of which self-isolation and inter-personal distancing are only the most common examples. Consider the following: offering voluntary work and assist others with basic activities that contain the social bubble of the contagion; providing locations for assistance to patients during the emergency (Margolies, 2020); creating and running apps for tracking the virus; performing jobs in critical, severe, and extreme conditions, for extended hours and sometimes with high personal health risks. The hardship of self-suffering was mitigated by a dose of humour, spontaneous generosity, and good feeling: during Easter 2020 families toasted across balconies; musicians offered unplugged versions of their songs from their rooms; DJs diffused thumping sounds from roofs; Facebook groups and WhatsApp chats were created to keep neighbours connected and to organize support groups to help people with information, caretaking, support (material, practical, and economic), and donations (Carlsen et al., 2021: 127).

These actions are all celebrations of life and ways to counter death. We are not claiming that such an informal and spontaneous form of engagement did not have any limit, such as the fact that many citizens in need have not been reached (Carlsen et al., 2021: 129). Yet, in their respect for inter-dependence and unity in fragility, they are important as they present the 'residual' of a reality not dominated by the exclusive emphasis on short-term utility. In nonviolent political thought, an action has quality if there is no immediate individual pay-off for the individual (Jahanbegloo, 2021: 27 on the difference with Mill's utilitarianism).

For other categories of people, physical distancing is not a limitation, but a sort of dream. For instance, for refugees across Europe, to keep inter-personal distance during the day and even respecting home isolation is impossible. Yet, European associations and groups risked their lives by providing water and sanitation facilities, training midwives and medical students on ways to maintain basic hygiene measures and keep social distance. In Greece, high-risk residents (the elderly and individuals with chronic diseases) were moved to a safer location (as shown by the Europe Must Act campaign). ${ }^{2}$

\footnotetext{
${ }^{2}$ https://www.europemustact.org/citiesmustact.
} 
We conclude with the contrast between citizens and governments because it is telling - at least for some states. Although citizens showed actions of self-suffering for the flourishing of life, some European governments did little or nothing to counter a ruthless administration of death and life. Some countries practically ignored those vulnerable in society (letting them die without help), such as prisoners, undocumented migrants, refugees, migrants in holding facilities, people with mental illnesses, and homeless. The government of Romania exploited the pandemic to impose even more restrictions on abortion. The lockdown has increased the barriers that bar poor women from accessing clandestine abortion drugs, meaning for some of them a sentence to death (Diniz and Carino, 2020). 'Vaccine nationalism' (the race of European governments to lock in early access of vaccines) is another type of behaviour that consciously sentences to death non-citizens, denying unity in fragility and openness (Bollyky and Bown, 2020).

\section{The social dimension: building social capital from people power}

The pandemic has hit hard the world of social movements and non-armed resistance, even though, arguably, its decline in effectiveness started earlier (Chenoweth, 2020). Research shows that civil and political engagement continued during the pandemic (Borbáth et al., 2021; Carlsen et al., 2021). Yet, there is evidence of lockdown measures turning into human rights abuses and postponement of elections (USIP, 2020). COVID-19 lockdowns and measures of inter-personal distancing challenged the legitimacy of rallies and reduced the platforms available to the opposition. We witnessed examples of gathering to protest against the shutdown (Mathis, 2020 on the USA, but the situation in Europe was comparable) or denying the existence of COVID-19 from London to Rome; of discussions on whether to keep open churches in Catholic Italy during the lockdown; of heated debates to hold gathering, such as the 8th of May rally in Spain in spite of the fact that COVID-19 was already circulating and claiming victims in neighbouring countries.

Yet, not all facts conform to this narrative of 'executive power up, social movements down'. In a way, the pandemic forced social movements and the nonviolent opposition to bring creativity in their methods of collective action. It accelerated the process of thinking outside of the box. With hindsight, the 2020 unprecedented situation, with two periods of lockdowns for a number of European countries, might have been a trigger event (Benros et al., 2020). Social movements and organizations around the world are rethinking their own strategies to address the criticism of being a vehicle for the spread of the virus. They are going through a phase of tactical innovation (Chenoweth, 2020: 80; Chenoweth et al., 2020b), in which less emphasis is put on organizing rallies and more on alternative tactics (Chenoweth et al., 2020a) and building alternative institutions to forge self-sufficiency and address community problems. Rallies respecting social distancing are now common - even the British Prime Minister Boris Johnson raised concerns about the disproportionate response of the London Metropolitan Police to Sarah Everard's vigil in March 2021 (BBC, 2021). In Greece and Germany, empty chairs demonstrations have raised awareness. ${ }^{3}$ Online tools to gather and continue political and social struggles have proliferated. Incidentally, the pandemic also affected the social behaviour of the business community, with plenty of examples of philanthropy and business-supported crowdfunding.

But, let us go back to the use of the digital space. This is a double edge sword for social movements. In 2020/2021, it was objectively difficult to protect activists in the digital space and not to give information to governments, including of course authoritarian leaders. We even witnessed the attempts by some regimes, such as the Serbian government, to curb opposition using digital tools. ${ }^{4}$ This leads to the question whether digital connection may be considered a human right or not. Indeed, apart from the equally important issue of education going online, there is also the

\footnotetext{
${ }^{3}$ https://www.hessenschau.de/wirtschaft/leere-stuehle-protest-gegen-corona-misere-gastronomen-fuerchten-pleitewelle, aktion-leere-stuehle-100.html.

${ }^{4}$ https://bird.tools/wp-content/uploads/2020/04/serbia_march_twitter-1.pdf.
} 
fact that protesting goes online, making the digital rights a key political territory for the European nonviolent collective social action of the near future.

When the use of the internet is excluded, classic methods of collective action re-emerge, such as microphones and bicycles to go around the town and raise awareness; fliers in visible places (to communicate the availability to help); and using roofs to connect people. More pertinently perhaps, the pandemic has not only changed the methods of protesting; it has also provided the opportunity to 'adjust the frame' for existing movements critical of the politicians in office (Chenoweth, 2020: 81). In some cases, it has provided the very reason for collective mobilization of citizens who had not been previously active. Chenoweth argues that the questionable handling of the pandemic by populist governments is an opportunity to build momentum and capitalize on citizens' need for change. Several social movements have adjusted their objectives, becoming more focused on the production of knowledge and meaning. They are playing the role of watchdogs of public policies and becoming vehicles of popular education (Pleyers, 2020).

These changes in tactics and aims may have consequences at the transnational level. Following Krunke et al. (2020), transnational grass-root movements grew already before the crisis. In the near future, the global dimension of the pandemic may produce social capital at the transnational level to counteract states' and regions' nationalism and closures. In the European Union, Hungary and Poland have exploited the state of emergency to endanger rule of law. ${ }^{5}$ At the same time though, social capital at the transnational level is slowly consolidating. ${ }^{6}$ Albania, for example, ${ }^{7}$ sent doctors to Italy in the attempt to help the collapsed health system. There is also an emerging transnational public opinion demanding to penalize Hungary and Poland with the legal and monetary means available to the European Union - in July 2021, the President of the Commission asked Hungary to ditch its anti-LGBT law or face the full force of EU law.

To conclude, there is evidence supporting the narrative that the pandemic offered governments opportunities for the suspension or limitation of normal democratic collective mobilization. But, at least for some forms of collective action, COVID-19 led movements to adjust the frame, mobilize citizens against the very visible violations of their liberties, and the mishandling of the crisis, and think creatively about mobilization and digital rights.

\section{Shaping a diverse ecological citizenship}

In this section, we move to the macro level. What can nonviolence as framework tell us about the relationship (and conflict) between human beings and their planet? Before we mobilize the framework of nonviolence a third time, we start with the banal but true observation that the pandemic has generated some lessons about how we humans can change our relationship with the environment. We had to acknowledge that the resilience of our society depends on a resilient environmental system. ${ }^{8}$ We have reduced private and collective transport. We have adjusted to remote working. We have discovered that farm-to-door commerce has a place in the most advanced European cities. We have seen the improvement in the air quality of our cities, as well as in the conditions of seas and beaches.

The framework of nonviolence may help us to re-interpret these observations as opportunities to develop a wider, inclusive, and social (and not just environmental) notion of sustainability. For nonviolent political theory, this relationship with the planet goes hand in hand with the political utopia of the uplift of all in an integral democracy or Ramarajya (Jahanbegloo, 2021: 35). It is therefore a political ecology. This political ecology starts from the biocentric ethos (Naess, 1973) and draws attention to the consequences of our actions for non-humans, with obvious

\footnotetext{
${ }^{5}$ https://democracy-reporting.org/dri_publications/the-rule-of-law-stress-test-eu-member-states-responses-to-covid-19/.

${ }^{6} \mathrm{https} / /$ www.opendemocracy.net/en/pandemic-border/times-pandemic-transnational-solidarity-not-national-borders/.

${ }^{7}$ https://www.euronews.com/2020/03/28/albania-sends-30-doctors-and-nurses-to-italy-to-help-fight-the-covid-19-pandemic.

${ }^{8}$ https://www.eea.europa.eu/publications/covid-19-and-europe-s/covid-19-and-europes-environment.

${ }^{9}$ https://www.undp.org/blogs/ocean-and-covid-19.
} 
implications for personal autonomy and civic awareness (Jahanbegloo, 2021: 61) - and, by extension, ecological awareness.

This approach to sustainability takes seriously into consideration the next generations in our present life and policy choices. In the nonviolent literature, we find such connection towards new and old generations well explained by the original approach of Aldo Capitini. In pages echoing the re-interpretation of Greek philosophy and religion brought about by Otto (1954), Capitini theorized the compresence (compresenza in Italian) of those who are alive and those who are dead, pointing to nonviolent action as the moment in which humans embrace the life cycle overcoming barriers across generations, species, time, and epochs (Capitini, 1998).

Compresence is 'the connection constructed between all men, both living and dead, at the moment when they present themselves as moral subject, in contrast with the given reality, and acting as members of an ideal community' (Capitini, 2000: 105). In any action of value, human beings keep past generations alive and include the new ones. In this way, they overcome the finite nature of our individual lives, and thus the conception of individual material death as the end of everything, reconnecting it to the lives of those who are dead, yet to come and even of other species. A philosophy exclusively concentrated on those who are alive and their problems - Capitini argued - is short term. It has no use for the state of the planet and the survival of life. It also makes no sense as each party that takes part in this intergenerational conflict 'will become the other' at one point in time (Gottschalk, 1990: 204). By excluding the dead, it excludes those who are close to them Capitini lyrically wrote about these people as 'the halved, the exhausted, the crushed'. It places in parenthesis the future humiliated and offended humanity, because it applies categories that only suit the living and the active humans. This is also valid for other species, who also need a philosophy not exclusively obsessed with the problems of humans who are alive today.

And this is where the other notions of sustainability (notably, environmental sustainability) enter the frame. If we are co-present with other generations and other species in any action we undertake, we should contribute to the care and well-being of the planet. This duty of care is the only way to overcome the barriers between living, dead, future generations, and other species. The Gandhian tradition predicates neither an abstract system of intergenerational environmental justice, with subsequent rights of future or past generations, nor any sort of worship or sacredness of nature. What is key is the quality of the everyday relationship between human beings, other species, and nature (Godrej, 2015: 47). In particular, a nonviolent approach to the sustainability issues is not detached from human material needs, as well as questions of social justice and power (Godrej, 2012, 2017). Yet, it is not a relation master-slave and it certainly goes beyond 'the shallow ecology movement' that provides exclusively 'health and affluence of people in developed countries' (Naess, 1973: 95). To the contrary, nonviolence overcomes the artificial division between human beings and the environment, as hurting the environment is hurting ourselves, past and future generations, as well as our species.

Thus, the question is what can nonviolence offer to cultivate the opportunities provided by the pandemic and face the environmental challenge ahead? Godrej argues that the Gandhian tradition is a form of ecological citizenship, which has two dimensions. To begin with, it is an ethics of scrutiny of one's bodily consumptive behaviour. This includes vegetarianism, as well as smaller day-to-day commitments, such as the management of personal carbon footprint. The second form is an 'active, participatory, and warrior-like form of citizenship in which the physicality of the body allows for an aggressive, combative, and even disruptive form of nonviolent political action' (Godrej, 2012: 438). Following Godrej, ecological citizenship has a bodily dimension and a social-participatory dimension. One example is the movement inspired by Greta Thunberg. ${ }^{10} \mathrm{We}$ draw attention to a third dimension of citizenship, which is crucial to complement the other two. James Tully has argued for diverse citizenship, a form of civic awareness (Jahanbegloo, 2021: 61) as praxis, as continuous negotiation of practices of citizenship which takes place at any level

\footnotetext{
${ }^{10} \mathrm{https} / / /$ www.nonviolent-conflict.org/blog_post/greta-thunberg-and-the-power-of-strategic-movement-messaging/.
} 
(Tully, 2014). This approach can be extended to include non-humans and nature, building up here and now a new reality with nature. For us, diverse means that nonviolent citizenship embraces individuals across status and borders, human beings and animals, us and the planet, the past, present, and future generations. It is 'ecological' in this deep sense. Citizenship is not a status, something that is granted from above. It is an active construction of the ends we want to see incarnated in our means (Tully, 2008).

From this perspective of diverse and ecological citizenship, the slow violence we mentioned in the Introduction should not tackled exclusively by international law, different relations between nation states, or a different economic regime. Slow violence is fundamentally a problem of human relations, and in particular a lack of both person and people power to 're-negotiate' the dominant practices of environmental exclusion and exploitation. A key locus of such a re-negotiation in the post-pandemic is the city, where we witnessed the strongest efforts to learn to reduce food waste, especially against the backdrop of rising poverty; improve and extend bike lanes; foster the development of remote working .

Back again to Gandhi, in his writings on the economy he urged us to re-think (not abolish) the process of industrialization (Ninan, 2009), also because of the consequences on the environment. Gandhi was worried about environmental pollution and the appalling working conditions in industry, with workers forced to inhale contaminated, toxic air. He expressed those concerns in Indian Opinion on 5 May 1906: 'Nowadays, there is an increasing appreciation among enlightened men of the need for open air'. A nonviolent approach to political economy highlights the consequences of our production and consumption systems, urging an overhaul of the entire production and consumption process, including nature and future generations (Schumacher, 1993; Cante and Torres, 2019). Yet, nonviolence does not simply require criticizing the status quo. It asks people to become trustees of their communities to build an alternative. Today, this has some connections with the European Union's policy paradigm of the circular economy and to the proposal for a European carbon tax. The commitment of both communities and institutions is key for health and wellbeing of both humanity and nature.

Another opportunity and lesson-to-draw concerns science. The pandemic taught us that the key tool for the construction of a new inclusive order is science - in a new covenant restoring trust with industry and above all society. A rejection of science and expertise, along with conservatism or parochialism, cannot be a solution for human survival and the conservation of nature. The use of genome sequencing is key to track the circulation and evolution of viruses such as COVID-19. The challenge ahead is to re-think the governance of science and innovation, reconnecting science with citizens and the long-terms implications of technology and innovation for the planet. We can draw on the experience of citizens science to track, collect data, and better understand the virus and its consequences. ${ }^{11}$ This is nothing new at the European level (see for instance: Science Communication Unit UWE, 2013). Yet, today's effort is to bolster these experiments, and more generally the connection between science, on the one hand, and the dyad of innovation and precaution as foundations of regulatory choice in the European Union (on this, we elaborate in Baldoli and Radaelli, 2021). It has been already said that science can strengthen attachment to the personal, social, and environmental dimensions of place, and additionally it has the potential to enhance both individual and collective social-ecological meanings (Toomey et al., 2020). Science can help to go beyond the rigid distinction between nature and human beings, future and past generations, as current research on epigenetics is already showing (Sweatt, 2019); and to avoid deforestation ameliorating food production, as technological advances are already leading to the use of less pesticides without giving up on seed diversity and food sovereignty.

\footnotetext{
${ }^{11}$ See, for instance, the different projects on COVID-19 at https://www.citizenscience.org/covid-19/ as well as the Coronareport at https://www.spotteron.net/projekte/coronareport-app.
} 
To sum up, the lens of nonviolence shapes a different citizenship, able to build up a different mode of governance in which the different stakeholders work together (including nature and future generations) in the construction of a new sustainable reality.

\section{Conclusion}

By taking an original angle, that is, nonviolence, we have contributed to the emerging social scientific literature on the effects of the pandemic on governance and collective behaviour. Our findings are contingent on the concept of nonviolence we adopted. Ours is one of the many possible ways to think about nonviolence, although we drew on a robust tradition of Gandhian political thought and nonviolent scholarship.

With this limitation, we can turn to the first research question on the how and where of nonviolence and the second question on the implications. We found that nonviolence was a spontaneous individual and social praxis in the pandemic, with implications on the limits of necropolitics, the policy narratives limited to the two poles of markets and states, and the relation between science and the environment. Although the evidence is not conclusive at all, COVID-19 has re-framed nonviolent collective action or enriched its repertory.

The emergence of nonviolence in individual and mass behaviour should not be taken for granted, however. It is not an unlimited resource present everywhere and every time. It needs to be cultivated and accompanied by responses at the level of public policies and governance. The lack of coherent governmental responses, vaccine nationalism, and the fragmentation of public policy (across the levels of governance and across sectors such as education, the economy, and public health) have generated an atmosphere where frustration, anger, and lack of trust may soon trump trust. And the spirit of unity in fragility shown in Spring 2020 may well be dissipated by institutional conflicts and vaccine wars.

Normatively, our findings suggest a repositioning of individuals in terms of actorness in public policy (as per our discussion of swaraj and sarvodaya and the themes presented in economics by Wendy Carlin). They also suggest that sustainability in its social and environmental components needs robust political thinking about 'unity in fragility' and openness to our compresence with other generations and living beings. Finally, there are lessons about science and society that we have barely sketched, but point to an exciting research and political agenda for the re-construction of trust in our societies.

Perhaps the most useful lesson is about the model of the individual. Although there are several domains of behaviour where individuals conform to the laws of the homo economicus, our exploration sends signals about the capacity of the individuals to use their body to protect others, to fight necropolitics, to provide liberation and to feel compresence. In an era where social scientists are debating issues of bounded rationality, cognition, and emotional responses to crises, our nonviolent perspective offers a grand-angle that goes well beyond these issues, inviting a complete re-examination of the centre of every social enquiry: the human being and its relationship with life, death, the others, the new generations, and the planet.

Funding. The research has been funded by the University Association for Contemporary European Studies (UACES), Grant European Nonviolence Network.

Acknowledgements. We wish to acknowledge the support of the University Association for Contemporary European Studies, grant European Nonviolent Network (https://www.uaces.org/networks/european-nonviolence-network). An early version was delivered to the European University Institute, RSCAS Workshop on Testing Europe's Democratic Legitimacy in the COVID-19 Crisis, 16 February 2021. We are grateful to the participants and in particular to Daniele Caramani, Philipp Genschel, Brigid Laffan, Kalypso Nicolaidis, and Anja Thomas. Many thanks to Filippo Troconi and Elisabetta De Giorgi for their assistance and suggestions throughout the review process. The manuscript greatly improved thanks to the reports sent by two anonymous reviewers. The usual disclaimer applies. 


\section{References}

Ackerman P and DuVall J (2001) A Force more Powerful: A Century of Nonviolent Conflict. New York: Palgrave.

Adler-Nissen R and Pouliot V (2014) Power in practice: negotiating the international intervention in Libya. European Journal of International Relations 20, 889-911.

Agamben G (2020) L'invenzione di una Epidemia. Available at https://www.quodlibet.it/giorgio-agamben-l-invenzionedi-un-epidemia.

Arendt H (1998) The Human Condition, 2nd edn., Chicago: University of Chicago Press.

Atack I (2012) Nonviolence in Political Theory. Edinburgh: Edinburgh University Press.

Baldoli R (2018) Reconstructing Nonviolence. A New Theory and Practice for a Post-Secular Society. Abingdon: Routledge.

Baldoli R and Radaelli CM (2019) What has nonviolence got to do with the EU? JCMS: Journal of Common Market Studies 57, 1165-1181.

Baldoli R and Radaelli CM (2021) Foundations of regulatory choice: precaution, innovation and...nonviolence? Journal of Contemporary European Research 17, 186-204.

BBC (2021) Sarah Everard vigil: Women arrested at Clapham gathering. Available at https://www.bbc.co.uk/news/av/uk56400147.

Benros I, Wilmot P and Warburg S (2020) COVID-19 can trigger revolution - here's how! International Center for Nonviolent Conflict. Available at https://popularresistance.org/covid-19-can-trigger-revolution-heres-how/.

Bollyky TJ and Bown CP (2020) The tragedy of vaccine nationalism: only cooperation can end the pandemic. Foreign Affairs, September/October 2020.

Bondurant JV (1988) Conquest of Violence. The Gandhian Philosophy of Conflict. Princeton: Princeton University Press, Original Edition: 1958.

Borbáth E, Hunger S, Hutter S and Oana I-E (2021) Civic and political engagement during the multifaceted COVID-19 crisis. Swiss Political Science Review 27, 311-324.

Cante F and Torres WT (Eds) (2020) Nonviolent Political Economy. London: Routledge.

Capano G, Howlett M, Jarvis D, et al. (2020) Mobilizing policy (in)capacity to fight COVID-19: understanding variations in state responses. Policy and Society 39, 285-308.

Capitini A (1998) Scritti filosofici e religiosi. Perugia: Fondazione Centro Studi Aldo Capitini.

Capitini A (2000) A philosopher of nonviolence. Diogenes 48, 104-119.

Carlin W (2020) COVID-19 is Resetting the Way we Talk about the Economy, Financial Times. Available online at https:// www.ft.com/content/cb827cea-849d-11ea-b6e9-a94cffd1d9bf (last accessed on the 13 August 2020).

Carlsen HB, Toubøl J and Brincker B (2021) On solidarity and volunteering during the COVID-19 crisis in Denmark: the impact of social networks and social media groups on the distribution of support. European Societies 23(sup1), 122-140.

Cavanagh CJ (2014) Biopolitics, environmental change, and development studies. Forum for Development Studies 41, $273-294$.

Chenoweth E (2020) The future of nonviolent resistance. Journal of Democracy 31, 69-84.

Chenoweth E, Shetty S and Smith M (2020b) Reimagining Social Movements and Civil Resistance during the Global Pandemic. Harvard Carr Center, COVID-19 Discussion Paper Series. Available at https://carrcenter.hks.harvard.edu/ files/cchr/files/200416_covid_discussion_paper.pdf\#: :text=Reimagining\%20Social\%20Movements\%20and\%20Civil\%20 Resistance\%20during\%20the,than\%20ever\%20in\%20holding\%20governments\%20accountable.\%20Erica\%20Chenoweth.

Chenoweth E, Choi-Fitzpatrick A, Pressman J et al. (2020a) The global pandemic has spawned new forms of activism - and they're flourishing. The Guardian, 20 Abril 2020. Available at https://www.theguardian.com/commentisfree/2020/apr/20/ the-global-pandemic-has-spawned-new-forms-of-activism-and-theyre-flourishing.

Diniz D and Carino G (2020) COVID-19 and the wounded uterus. El País in English. Available at https://english.elpais.com/ opinion/2020-07-01/covid-19-and-the-wounded-uterus.html.

Esposito R (2020) I partiti e il virus: la biopolitica al potere. La Repubblica. Available at https://rep.repubblica.it/pwa/commento/2020/02/28/news/i_partiti_e_il_virus_la_biopolitica_al_potere-249847971/.

Foucault M (1998 (1976)) The Will to Knowledge - The History of Sexuality, vol. 1. London: Penguin Books.

Gandhi MK (1920) Religious authority for non-cooperation. Young India, 25 August.

Gandhi MK (1942) The eternal problem. Harijan. 14 March.

Gandhi MK (1996) Selected Political Writings, ed. by Dalton D. Indianapolis/Cambridge: Hackett.

Gandhi MK (1997) 'Hind Swaraj' and Other Writings. Cambridge: Cambridge University Press.

Gandhi MK (1999) Collected Works of Mahatma Gandhi. New Delhi: Publications Division Government of India.

Gillett H, Martin B and Rust C (1996) Building in nonviolence: nonviolent struggle and the built environment. Civilian-Based Defense 11, 4-7.

Gjerde LEL (2021) From liberalism to biopolitics: investigating the Norwegian government's two responses to COVID-19. European Societies 23(sup1), 262-274.

Godrej F (2012) Ascetics, warriors, and a Gandhian ecological citizenship. Political Theory 40, 437-465.

Godrej F (2015) Culture and Difference: Non-Western Approaches to Defining Environmental Issues. In Gabrielson T, Hall C, Meyer JM et al. (eds), Oxford Handbook of Environmental Political Theory. Oxford: Oxford University Press.

Godrej F (2017) Gandhi, Foucault, and the politics of self-care. Theory and Event 20, 894-922. 
Gottschalk SS (1990) Toward a nonviolent reconceptualization of intergenerational conflict. In Kool VK (ed), Perspectives on Nonviolence. Recent Research in Psychology. New York: Springer.

Jahanbegloo R (2014) Introduction to Nonviolence. New York: Palgrave.

Jahanbegloo R (2020) The Courage to Exist. Philosophy of Life and Death in the Age of Coronavirus. Himayatnagar, India: Orient Blackswan Private Limited.

Jahanbegloo R (2021) Mahatma Gandhi: A Nonviolent Perspective on Peace. London and New York: Routledge.

Kaplan O (2017) Resisting War. How Communities Protect Themselves. Cambridge: Cambridge University Press.

Krunke H, Petersen H and Manners I (Eds) (2020) Transnational Democracy: Concepts, Challenges and Opportunities, Cambridge: Cambridge University Press.

Lee JC (2020) The Necropolitics of COVID-19. Available at https://africasacountry.com/2020/04/the-necropolitics-of-covid-19.

Mantena K (2012) Another realism: the politics of Gandhian nonviolence. American Political Science Review 106, 455-470.

Margolies J (2020) When N.Y. needed hospital space, film location scouts pitched. New York Times. Available at https://www. nytimes.com/2020/04/29/nyregion/coronavirus-nyc-volunteers-location-scouts.html.

Mathis D (2020) Too much coverage of U.S. anti-shutdown Protests? A journalist chimes. Minds of the Movement. ICNC. Available at https://www.nonviolent-conflict.org/blog_post/too-much-coverage-of-u-s-anti-shutdown-protests-a-journalistchimes-in/.

Mbembe A (2019) Necropolitics. Durham, NY: Duke University Press.

Naess A (1973) The shallow and the deep, long-range ecology movement. A summary. Inquiry: A Journal of Medical Care Organization, Provision and Financing 16, 95-100.

Nagler MN (2014) The Nonviolence Handbook: A Guide for Practical Action. San Francisco, CA: Berrett-Koehler Publishers.

Ninan AS (2009) Gandhi's technoscience: sustainability and technology as themes of politics. Sustainable Development 17, 183-196.

Nixon R (2011) Slow Violence and the Environmentalism of the Poor. Cambridge: Harvard University Press.

Ongaro E (2020) Philosophy and Public Administration: An Introduction, 2nd Edn. Cheltenham: Edward Elgar Publishing.

Otto WF (1954) The Homeric Gods: The Spiritual Significance of Greek Religion. London: Thames and Hudson.

Pleyers G (2020) Have movements disappeared during lockdown? Minds of the Movement. ICNC. Available at https://www. nonviolent-conflict.org/blog_post/have-movements-disappeared-during-lockdown/.

Robertson H and Travaglia J (2020) The necropolitics of COVID-19: will the COVID-19 pandemic reshape national healthcare systems? LSE Impact Blog. Available at https://blogs.lse.ac.uk/impactofsocialsciences/2020/05/18/the-necropolitics-ofcovid-19-will-the-covid-19-pandemic-reshape-national-healthcare-systems/.

Schumacher EF (1993) Small is Beautiful: A Study of Economics as if People Mattered. London: Vintage.

Science Communication Unit, University of the West of England, Bristol (2013) Science for Environment Policy In- depth Report: Environmental Citizen Science. Report produced for the European Commission DG Environment, December 2013. Available at http://ec.europa.eu/science-environment-policy.

Sharp G (1973) The Politics of Nonviolent Action. Part One: Power and Struggle. Boston: Porter Sargent Publishers.

Sweatt JD (2019) The epigenetic basis of individuality. Current Opinion in Behavioral Sciences 25, 51-56.

Taylor M (2019) Doctors call for nonviolent direct action over climate crisis. The Guardian. 27 June 2019. Available at https:// www.theguardian.com/environment/2019/jun/27/doctors-call-for-nonviolent-direct-action-over-climate-crisis.

Toomey AH, Strehlau-Howay L, Manzolillo B, et al. (2020) The place-making potential of citizen science: Creating social-ecological connections in an urbanized world. Landscape and Urban Planning 200, 103824.

Tully J (2008) Public Philosophy in a New Key: Volume 2, Imperialism and Civic Freedom. Cambridge: Cambridge University Press.

Tully J (2014) On Global Citizenship. London and New York: Bloomsbury.

USIP United States Institute of Peace (2020) People Power in a Pandemic. Webinar with 'Activitists and Peacebuilders'. Tuesday May 19 May 2020. Available at https://www.usip.org/events/people-power-pandemic.

Van Goelst Meijer S (2017) The nonviolent sacrifice: the role of Tapasya in nonviolence. In Duyndam J, Korte A and Portuis M (eds), Sacrifice in Modernity: Community, Rituals, Identity. Leiden/Boston: Brill.

Voorberg WH, Bekkers VJJM and Tummers LG (2015) A systematic review of co-creation and co-production: embarking on the social innovation journey. Public Management Review 17, 1333-1357.

Weible CM, Nohrstedt D, Cairney P, et al. (2020) COVID-19 and the policy sciences: initial reactions and perspectives. Policy Sciences 53, 225-241.

Zandbergen D and Uitermark J (2020) In search of the smart citizen: republican and cybernetic citizenship in the smart city. Urban Studies 57, 1733-1748.

Zuboff S (2019) The Age of Surveillance Capitalism: The Fight for a Human Future at the New Frontier of Power. New York: Public Affairs.

Cite this article: Baldoli R, Radaelli CM (2022). Unity in fragility: nonviolence and COVID-19. Italian Political Science Review/Rivista Italiana di Scienza Politica 52, 378-390. https://doi.org/10.1017/ipo.2021.38 